\title{
Pontoppidans Lykke-Per i lyset af Kierkegaards teologi
}

\author{
Stud.theol. \\ Theis Schønning Johansen, Københavns Universitet
}

\begin{abstract}
This article presents a reading of Pontoppidan's Lucky Per in comparison with the theological anthropology of Søren Kierkegaard. To this end, the article follows Kierkegaard's conception of despair as developed in The Sickness unto Death and the act of belief as illustrated in Fear and Trembling. Pontoppidan knew the authorship of Kierkegaard well. This article indicates that Pontoppidan in writing Lucky Per was heavily inspired by the development of Self as presented by Kierkegaard. Finally, the article discusses to what extent Per in his final form stands in a relationship to something divine.
\end{abstract}

Keywords: Pontoppidan - Kierkegaard - Despair - Personality - Belief - Lucky Per - Sickness unto Death - Fear and Trembling - Becoming a Self.

Henrik Pontoppidan betragtede ikke sig selv som kristen forfatter. Han frabad sig indirekte gennem sine noveller og romaner, at man tolkede dem i en sådan retning. Således også i Lykke-Per, hvor det om Per Sidenius bl.a. hedder: "[han følte], at han hverken var eller havde været eller nogensinde vilde kunne blive en virkelig troende Kristen. Ja, han kunde ikke engang længer ønske at blive det". I forlængelse heraf er det af litterat Børge Kristiansen blevet hævdet, at Kierkegaards og Pontoppidans identitetsfilosofi i mangt og meget følges ad, men er afgørende forskellige på det punkt, der omhandler gudsforholdet. $^{2}$ Det er imidlertid ikke så entydigt, hvad Pontoppidan antyder, og Kristiansen fastholder, at Per Sidenius i sin endelige selvantagelse skulle være blottet for et egentligt forhold til noget guddommeligt. Sidenius er flere gange i berøring med det guddommelige i forskellige skikkelser, og da han som ensom, dog lykkelig vejassistent i Vestjylland kommer af dage som følge af en kræftsygdom, er det med ro i sindet, fordi han har ladet sig føre til sin endelige bestemmelse af en

1. Henrik Pontoppidan, Lykke-Per, Gyldendals Biblioteksserie $20 \& 21$ (København: Gyldendal 1964), II: 269.

Kildehenvisninger markeres hhv. I og II.

2. Børge Kristiansen, 'At blive sig selv' og 'At vare sig selv' (København: Multivers 2007), 25. 
udefineret spøgelseshånd, som har ledt hans skridt. I det følgende vil jeg med udgangspunkt i disse dunkle magter præsentere en læsning af Lykke-Per, som viser en umiddelbart større sammenhæng mellem Kierkegaards teologiske antropologi og Pontoppidans identitetsfilosofi, end man i forskningslitteraturen tidligere har lagt vægt på. Dette gøres under inddragelse af Kierkegaards Sygdommen til Døden samt Frygt og Baven, som beskriver, hvorledes man bliver sig selv ved at stå i et forhold til det "Andet". Denne overvejelse synes også at være til stede hos Pontoppidan i Lykke-Per.

\section{Kierkegaards teologiske antropologi}

Det må formodes, at Pontoppidan har haft et indgående kendskab til Kierkegaard og dennes skrifter, hvilket fremgår af bibliotekets låneprotokoller. ${ }^{3}$ Det kan her dokumenteres, at Pontoppidan har beskæftiget sig med bl.a. Frygt og Baven samt Afsluttende Uvidenskabelig Efterskrift. Kendskabet til Kierkegaard bekræftes af Pontoppidan selv, idet han i en skrivelse fra d. 2. februar 1884 til sin forlægger, Frederik Hegel, udbeder sig Brandes' biografi om Kierkegaard. ${ }^{4}$ Denne biografi er en personlig skildring, der i høj grad handler om Brandes' eget forhold til Kierkegaards tænkning, hvorfor identitetsfilosofien naturligt fylder en stor del af biografiens indhold. Det er givetvis også her, at Pontoppidan selv er kommet under vejr med en "kierkegaardsk" identitetsfilosofi.

Værket Sygdommen til Døden er essentielt for at forstå, hvorledes Kierkegaard anskuer det at være menneske, eftersom det af forskere kaldes hans filosofisk-antropologiske hovedværk. ${ }^{5}$ Det er ikke muligt at bevise, om Pontoppidan faktisk har læst netop dette værk, men det er denne artikels tese, at tankerne om personlighedens udvikling har sin pendant i bl.a. Per Sidenius. Hertil må det erkendes, at selvom sporet ikke kan opdrives filologisk, kan den hermeneutiske påvirkning være ganske markant.

3. Peter Tudvad, "Pontoppidan og Søren Kierkegaard", http://www.henrikpontoppidan.dk/text/seclit/secartikler/tudvad.html (besøgt d. 24.01.19)

4. Henrik Pontoppidans brev til Frederik Hegel, 2. februar 1884, http://www.henrikpontoppidan.dk/text/kilder/breve/hegel_fr_senior/1884_02_02. html (besøgt d. 18.03.19)

5. Således er det defineret i Ettore Rocca, Kierkegaard (København: Gyldendal 2016). 
Sygdommen til Døden - fortvivlelse som selverkendelse

I Sygdommen til Døden hedder det, at menneskets selv er et "Forhold, der forholder sig til sig selv, eller er det i Forholdet, der forholder sig til sig selv". ${ }^{6}$ Selvet bestemmes med andre ord som det, der allerede er anlagt i den enkelte, og som det, der forholder sig til dette selv. Mennesket bliver et selv, når det ved at forholde sig til sig selv bliver sig selv: "Ethvert Menneske er nemlig primitivt anlagt som et Selv, bestemt til at blive sig selv" (SD, 91). Det er således ikke selvets opgave at virkeliggøre en eller anden abstrakt idé, men slet og ret blive og vedkende sig det selv, man allerede er og er bestemt til at være. ${ }^{7}$ Selvet står imidlertid ikke isoleret, men er sat af et "Andet" (SD, 73). I dette forhold, hvor selvet er det, der forholder sig til sig selv som sat af noget andet, opstår muligheden for at fortvivle. Fortvivlelsen er kort sagt, med Anti-Climacus' egne ord, et "Misforhold i et Forhold, der forholder sig til sig selv" (SD, 74). I fortvivlelsen bliver selvet fremmed for sig selv og fremmed for fordringen om at blive sig selv, fordi selvet forvirrer de elementer eller skikkelser, der definerer selvet. Selvet er, hedder det andetsteds, en syntese: "Selvet er den bevidste Synthese af Uendelighed og Endelighed, der forholder sig til sig selv" (SD, 87). Endelighed og Uendelighed er umiddelbart modsatrettede elementer, der altså holdes sammen i og af selvforholdet, eftersom mennesket forholder sig til sig selv som bestånde af disse modsatrettede, uensartede skikkelser. Forholdet mislykkes, fortvivlelsen opstår, såfremt man forsøger at gøre det ene element gældende foruden det andet eller der opstår ubalance (Grøn 1993, 90f). Fortvivlelsen er dog ikke nødvendigvis en bevidst tilstand, hvorfor Anti-Climacus opererer med tre former for fortvivlelse, hvor bevidsthedens bestemmelse definerer stadiet af fortvivlelse, der kan deles op i: den uegentlige fortvivlelse, svaghedens fortvivlelse og trodsens fortvivlelse.

Den uegentlige fortvivlelse består $i$, at man slet ikke er sig bevidst eller vil være sig bevidst om sin fortvivlelse. Den uegentligt fortvivlede er således ikke sin bestemmelse som ånd bekendt, hvorfor man beskriver denne tilstand som spidsborgerlighed eller åndløshed (SD, 97). Denne tilstand kan være tryg at opholde sig i, skønt den iflg. værkets pseudonyme forfatter er den allerfarligste tilstand, man kan befinde sig i (SD, 101).

Svaghedens fortvivlelse er en egentlig fortvivlelse, eftersom man som følge af en refleksion i selvet er blevet bevidst om, at man er fortvivlet. Denne fortvivlelse fremkaldes som oftest af "det Jordiske",

6. Søren Kierkegaard, Sygdommen til Døden. Søren Kierkegaards Samlede Værker (København: Gyldendal 1962), 73. Kildehenvisninger markeres SD.

7. Arne Grøn, Begrebet Angst hos Søren Kierkegaard (København: Gyldendal 1993), 90. 
hvilket mennesket egentligt ikke kan fortvivles over. Denne jordiske fortvivlelse udvikler sig dermed til en fortvivlelse over den svaghed, mennesket udviste ved at lade sig fortvivle over noget jordisk. Dermed er mennesket blevet i tvivl om, om det er et evigt selv - og ønsker følgelig at skaffe sig af med sig selv, eftersom svaghedens fortvivlede ikke ønsker at vedkende sig dette sit svage selv (SD, 117).

Trodsens fortvivlelse opstår som konsekvens af en øget bevidsthed i det fortvivlede selv, der nu ønsker at være sig selv på trods (SD, 122). Den fortvivlede vil på dette stadie "misbruge" det evige i selvet for at blive sig selv på trods af den magt, som oprindeligt satte selvet med dets bestemmelse (ibid.). Trodsens fortvivlede ønsker med andre ord at omdanne sig selv for at blive sig selv (Grøn 1993, 101). Da selvet er sat af det "Andet", magter selvet ikke at omdanne sig, hvilket det i fortvivlelsen bliver bevidst om: "Maaske støder et saadant experimenterende Selv, der fortvivlet vil være sig selv, idet det foreløbigt orienterer sig i sit concrete Selv, paa en eller anden Vanskelighed" (SD, 124). Vanskeligheden er sandsynligvis dette, at selvet allerede på forhånd er anlagt til dette bestemte selv, hvorfor det i fortvivlelsen ikke formår at omdanne sig i sit eget billede. En sådan fortvivlelse kan intensiveres og blive dæmonisk (Grøn 1993, 101). Den dæmonisk fortvivlede ønsker at hævde sig ved vanskeligheden, hvormed han prøver "med denne Qval at protestere hele Tilværelsen” (SD, 127). Den dæmonisk fortvivlede forsøger altså dermed at vise tilværelsens uretfærdighed ved at hævde sig ved sin vanskelighed mod den magt, som satte selvet.

Selvom vejen synes lang, så er fortvivlelsen en nødvendighed for at komme til sig selv (Grøn 1993, 111). Fortvivlelsen er en tvetydig størrelse, da den på samme tid er både "Menneskets Fortrin for Dyret" og "ikke blot den største Ulykke og Elendighed at være det, nei det er Fortabelse (SD, 74). Fortabelse er at blive ufri ved det selv, den fortvivlede i sin trodsighed forsøger at skabe, eftersom selvet da bliver en negativ bestemmelse ift. det selv, den fortvivlede ikke ønsker at vedkende sig.

Den Fortvivlelse, der er Gjennemgangen til Troen, er ogsaa ved Hjælp af det Evige; ved Hjælp af det Evige har Selvet Mod til at tabe sig selv for at vinde sig selv; her derimod vil det ikke begynde med at tabe sig selv, men vil være sig selv (SD, 122).

Hvis den fortvivlede ikke vil ende i fortabelse, må han have mod til at slippe det selv, han selv har forsøgt at skabe, men som ikke lader sig gøre. I fortvivlelsen bliver selvet bevidst om, at det er sat af et "Andet", hvormed det må vedkende sig dette selv ved at anerkende sin "sathed" og tabe sit eget trodsige selv, hvilket Anti-Climacus sammenfatter 
med: " $i$ at ville være sig selv grunder gjennemsigtigt i den Magt, som satte det" (SD, 105). Fortvivlelsen ville i sagens natur slet ikke opstå, såfremt selvet var i stand til at sætte sig selv, hvilket selvet erfarer i og med fortvivlelsen. I forlængelse heraf hævder Anti-Climacus, at modsætningen til fortvivlelsen er troen, eftersom det "Andet", der har sat selvet og dettes bestemmelse, i en "kierkegaardsk" sammenhæng er at forstå som Gud.

\section{Frygt og Beven - et troende selv}

Troen er med andre ord forholdet mellem Gud og den enkelte, som er blevet sig selv og herigennem grunder gennemsigtigt i den magt, som har sat selvet. Troen er imidlertid andet og mere end blot et forhold - det er ligeledes en forpligtelse i selvet, hvilket Frygt og Baven kortlægger. Abraham er et eksempel på den enkelte, fordi han som Guds udvalgte er "bleven høiere end det Almene". ${ }^{8}$ Fandtes troen ikke, måtte Abraham "hjemvises og udvises som en Morder" (FB, 52), men troen er et paradoks, som gør, at den enkelte står højere end det almene, hvorfor Abraham ikke betragtes som morder. Troen retfærdiggør med andre ord det, som Johannes de Silentio kalder en "teleologisk Suspension af det Ethiske" (FB, 53). Abraham er dermed ikke en tragisk helt, der bevæger sig inden for den etiske sfære. Hans tilsyneladende uhyrlige gerning kan ikke begrundes i det etiske, men alene forklares ved, at det er Guds befaling: "For Guds Skyld gjør han det, fordi Gud fordrer dette Bevis paa hans Tro, for sin egen Skyld gjør han det, at han kan føre Beviset" (FB, 56).

Pligten mod Gud er altså absolut, idet selvet grunder gennemsigtigt i Gud, hvormed menes, at den enkelte forholder sig "absolut til det Absolutte" (FB, 65). Det kan i Abrahams tilfælde betyde, at "Kjærlighed til Gud kan bringe Troens Ridder til at give sin Kjærlighed til Næsten det modsatte Udtryk af hvad der ethisk talt er Pligt" (Ibid.). Abrahams faderlige pligt mod Isak suspenderes som følge af hans forhold til Gud, hvilket han ikke vil kunne kommunikere ud, eftersom forholdet til Gud består i forholdet til sig selv; det er en lidenskab i den enkelte (FB, 66). Troen forudsætter dermed, at man "resignerer paa det Almene for at blive den Enkelte" (FB, 69). Troen lader sig med andre ord ikke oversætte i det etiske, eftersom det er et "privat Foretagende" (FB, 103), der ikke kan forstås af den, som ikke selv har gjort troens bevægelse. Den troende står med troen, som er fortvivlelsens modsætning, i et uformidlet, absolut forhold til det "Absolutte", hvilket alene kan komme til udtryk i den enkelte selv som passion og

8. Søren Kierkegaard, Frygt og Baven. Søren Kierkegaards Samlede Værker 5 (København: Gyldendal 1962), 61. Kildehenvisninger markeres FB. 
lidenskab. Det er denne bevægelse, der hermed er ridset op og som nærværende artikel vil argumentere for, at Pontoppidan i beskrivelsen af Per Sidenius' endelige selvantagelse er væsentligt inspireret af.

\section{Lykke-Per set gennem Kierkegaards antropologi}

Nærværende artikel indledtes bl.a. med Børge Kristiansens udsagn om, at Kierkegaards og Pontoppidans identitetsfilosofier er afgørende forskellige $\mathrm{i}$ forhold til synet på gudsforholdet $\mathrm{i}$ den personlige udvikling (Kristiansen 2007, 25). Børge Kristiansen hævder, at Lykke-Per alene skal betragtes ud fra sit forhold til Schopenhauers filosofi, som, mener han, danner grundlaget for forståelsen af Pontoppidans værk (ibid., 307). Kristiansens argument skal ikke udfoldes yderligere her, men det er væsentligt at bemærke, at tolkningen står stærkt i forskningstraditionen omkring Lykke-Per. Kristiansen er selv bevidst om, at der ikke er klare indicier på, at Pontoppidan skulle have læst Schopenhauer direkte, men at han har stiftet bekendtskab med Schopenhauers filosofi gennem bl.a. Nietzsche, som han har læst grundigt og hvis tanker, han inddrager hyppigt i sit forfatterskab. ${ }^{9}$

Som ovenfor anført er det klart, at Pontoppidan ligeledes har beskæftiget sig en hel del med Kierkegaards forfatterskab, hvorfor jeg nedenfor vil udfolde, hvorledes man kan læse Lykke-Per gennem en "kierkegaardsk" prisme, hvilket ikke nødvendigvis giver hele forklaringen på værket, men som åbner for flere andre interessante perspektiver i læsningen af Pontoppidan.

\section{Den uegentligt fortvivlede Per "Cosar" Sidenius}

Sidenius er i sine unge år ikke egentligt bevidst om sig selv, hvor han udfordrer de udstukne rammer, hvad enten det er i et opgør med sin fader, sin opvækst eller blot sit selv. Hele tiden er der noget, som modsiger den retning, han forsøger at skabe for sit eget selv, hvilket bl.a. eksemplificeres i kirkeklokkerne: "Allevegne og til alle Døgnets Tider brød den skurrende ind i hans Lykkedrømme ... advarende, kaldende" (I, 25). Bevidstheden om hans egen fortvivlelse lurer under overfladen, skønt den ikke får lov at komme frem. Således kan unge Sidenius føle sig fremmed i sit eget hjem (I, 15), eller han kan

9. Børge Kristiansen, "Trahimur. Om frihed og skæbne hos Henrik Pontoppidan”. http://www.henrikpontoppidan.dk/text/seclit/secartikler/kristiansen/trahimur. html (besøgt d. 18.03.19) 
senere føle sig helt hjemløs i samfundet $(\mathrm{I}, 120) .{ }^{10}$ Tilsyneladende har hans venner en idé om, at Sidenius står i et misforhold i forholdet til sig selv, eftersom de bevidner, at hans "sydende Livsmod, al den viltre, ærelystne Ungdomskraft [...] gjorde ham en Smule latterlig selv for hans bedste Venner" (I, 23). Den splittelse, som Sidenius udadtil befinder sig i, kommer virkeligt til udtryk, efter han i sin vildskab har indledt et kærlighedsforhold til Oline, som til Sidenius' store benovelse ligefrem forsøger at gøre "Angreb paa hans Dyd" (I, 28), hvorfor han som følge af hendes "grovkornede Ligefremhed" må bryde med hende. Denne vildskab og viltre ungdomskraft, han selv repræsenterer, byder ham altså på samme tid imod. Det tyder dermed på, at Sidenius ikke egentligt er sit selv bevidst, hvad hans skiftende sindsstemninger udtrykker bl.a. ved hans afrejse til København: "Om det saa var den fjerne Lyd af Kirkens Aftenklokke, der bares ud til ham over Engene som Hjemmets sidste Hilsen og Advarsel, saa vakte den nu kun hans forsonlige Følelser" (I, 30). De forsonlige følelser til hjemmet og kirkeklokkerne kølnes imidlertid hurtigt, efter han ved juletid atter indfinder sig i hjemmet, der dog ikke lever op til Sidenius' egne forventninger om gensynets glæde, hvorfor han kan vende tilbage til hovedstaden "fri og uafhængig" (I, 33).

Friheden og uafhængigheden, som møder Sidenius i København, skal ses som en frihed fra hjemmet og kirkeklokkerne, der på sin vis repræsenterer det selv, han er på flugt fra. I Sidenius' egen optik er han ikke skabt til "Hverdagsliv og Godtkøbslykke. Han følte Herskerblod i sine Aarer og krævede Plads til Højbords ved Livets Taffel blandt Jordens frie og frelse Mænd” (I, 42). Man øjner allerede her, at han identificerer sig med noget andet end det, han selv er, hvilket stadfæstes med det cæsariske motto, han senere citerer: "Jeg kommer, ser, sejrer!” (I, 48). Som bekendt er det jordiske i Sygdommen til Døden en forudsætning for, at man overhovedet fortvivles, eftersom den jordiske fortvivlelse er en katalysator for fortvivlelsen i selvet. Den jordiske fortvivlelse er foranlediget af, at man i sin umiddelbarhed ønsker at være noget andet, end det, man allerede er og skal blive (SD, 109). Her ønsker Sidenius ikke længere at være sig selv, men snarere en ny Cæsar, hvilket han understreger med sit hedonistiske livssyn: "Det gjaldt blot om at ville, hensynsløst og uden Anfægtelser at begare - og alle Livets Herligheder skulde blive ham til Del!” (I, 52). Det er bemærkelsesværdigt, at Pontoppidan benytter sig af samme processi-

10. Den litterære strømning, symbolismen, var på affattelsestidspunktet for $L y k$ ke-Per på sit højeste i Danmark. Pontoppidan kan være inspireret af dennes symbolske sprog, idet hjemmet og samfundet måske henviser til andet og mere end det konkrete hjem. Der kan her være tænkt på Sidenius' fremmedhed i sig selv og i forholdet til sig selv. 
on, som Kierkegaard gør brug af, da det om den umiddelbare, der vil være en anden end sig selv, hedder: "Saaledes hænger Selvet umiddelbart sammen med det Andet, ønskende, begjerende, nydende" (SD, 107). Kierkegaards pseudonym bruger tilmed Cæsar som et eksempel på den uegentligt fortvivlede, der kommer til at fortvivle over noget jordisk: "Naar saaledes den Herskesyge, hvis Løsen er "enten Cæsar eller slet Intet”, ikke bliver Cæsar, saa fortvivler han derover" (SD, 78). Som bekendt kan man ikke fortvivle over noget jordisk, men det frembringer alligevel en refleksion i den fortvivlede. Således også hos Sidenius, der netop ikke er Cæsar, men blot Per Sidenius, hvilket undertiden går op for ham.

Det er bl.a. Sidenius' udvekslingsophold i Dresack, der fører til, at han i modsætning til tidligere får en afmagtsfølelse over for naturen (I, 287), som bevirker, at han fortvivles over sin egen kunnen. Da han på dette tidspunkt er forlovet med Jakobe Salomon, bliver hun den naturlige samtalepartner i hans åndelige anfægtelser:

Desværre - saa ydmygende det end kan være for os - vi bliver nok nødt
til at indrømme, at vort Herredømme over Naturen foreløbig kun er
svagt befæstet; og heri maa man rimeligvis søge Forklaring paa den
Kendsgerning, at saa mange, endog blandt forholdvis oplyste Folk, i
Naturen kan se et Udtryk for en evig Styrendes uforanderlige Magt og
Vilje (I, 287).

Jakobe besvarer aldrig dette brev, men det beviser, at Sidenius' umiddelbarhed er blevet reflekteret som følge af hans afmagtsfølelse, hvorfor han i litteratur forsøger at finde det "altudtømmende Ord, der for evig havde tilintetgjort alle overtroiske Forestillinger om et "Hinsides"' (I, 289). Han skal bryde med umiddelbarheden, men selv $ø$ nsker han at forblive i den, hvad hans febrile søgen efter svar vidner om. Han er imidlertid blevet bevidst om, at han ikke er Cæsar. Det betyder ikke, at han dermed er kommet under vejr med sit selv, som han fortsat altså flygter fra, hvad han ligeledes bedyrer for Jakobe, da han hævder, at han efter sine åndelige anfægtelser atter er sig selv igen (I, 297). Derfor vender han sig udad, hvilket er en parallel til beskrivelsen i Sygdommen til Døden, hvori det om den umiddelbare med refleksion hedder: "hans Fortvivlelse er: ikke at ville være sig selv. Derimod falder det Latterlige ham rigtignok ikke ind, at ville være en Anden" (SD, 111). Den umiddelbare reflekterede ønsker ikke refleksionen, hvorfor han i det virksomme liv forsøger at gøre kål på den. Sidenius' udlandsophold bliver dermed en reaktion mod refleksionen, som ifølge Sidenius selv skyldes præsteblodet, der indvirker negativt på hans sind. 
Reaktionen mod refleksionen bliver helt konkret med oprøret mod kristendommen, som forsøger at kommunikere med ham gennem kirkeklokkerne. Præsteblodet, hævder Sidenius, er årsagen til de indre sindskampe, hvorfor han i sin iver efter at bryde med refleksionen skyder på et krucifiks for at overbevise sig selv om sin endelige løsrivelse fra kristendommens magt (I, 305). Sidenius rammer Kristus-figuren i siden, hvilket må være en reference til Bibelens fortælling om den romerske soldat, der spiddede Kristus i siden for at sikre sig, at denne var død (Joh 19,34). Kristus opstod som bekendt på tredjedagen, hvorfor døden ikke havde magt over ham. Således er Sidenius ej heller i stand til at kontrollere Kristi magt eller sit eget forhold hertil, eftersom det netop ikke lykkedes ham at destruere krucifikset, men netop at bekræfte Kristi magt ligesom hin romerske soldat. I sin blodrus bekræfter Sidenius sin cæsariske livsvilje med endnu et $\mathrm{C} x-$ sar-citat (I, 359), skønt han ved hjemkomsten til København kommer til større erkendelse af sig selv: "Nej - han blev nødt til at indrømme det - der var ikke det Stof i ham til en Verdenserobrer, som han havde troet" (II, 35). Dermed foretages retningen indefter i Sidenius' egen fortvivlelse.

\section{Svaghedens fortvivlelse belyst gennem Sidenius}

Som ovenfor anført er fortvivlelsen ikke noget ydre, som tilstøder én, men et misforhold i forholdet til sig selv. Sidenius er efter sit praktikophold kommet under vejr med sit eget misforhold i forholdet til sig selv, hvorfor han er blevet bevidst om sin egen fortvivlelse. På samme tid skammer han sig over den, hvorfor han da også bryder med de københavnske pengemænd, som ellers ville rejse penge til hans ambitiøse kanalprojekt, og til sin forlovedes søster, Nanny. Svaghedens fortvivlelse kulminerer, idet Sidenius agerer ligfølge for sin moder, der skal transporteres hjem ad søvejen:

\footnotetext{
Hvad der laa bag ham, svandt hen i Intethed. I en gammel værkbruden Præstekones Lignelse havde der aabenbaret sig for ham en Kraft, mod hvilken selv en Cæsars Vælde nu syntes ham fattig og ringe, - en Kraft og Storhed i Lidelsen, i Forsagelse, i Opofrelse (II, 116).
}

Selv betragter Sidenius denne hændelse som en "længe forberedt aandelig Fødsel i ham", der befæster hans egen fortvivlelse over den svaghed, han har udvist ved at fortvivle over det jordiske, at han altså ikke var Cæsar. Umiddelbart kunne denne passus henvise til en troens fødsel, selvom han, da han konfronteres med moderens ord om, at ærens alene er Kristi, får kuldegysninger som følge af de sjælekampe, der nu venter ham (II, 115f). Sidenius ønsker imidlertid ikke 
at skaffe sig af med sig selv, hvad ellers den i svagheden fortvivlende normalvis gør, men han ydmyger sig derimod i sin svaghed for den indre kraft, som havde "bjerget den ældre Slægt saa nogenlunde frelst gennem Datidens Ulykker" (I, 114). Kierkegaard er ikke afvisende for, at dette også lader sig gøre, da det er muligt at "svinge rigtigt af bort fra Fortvivlelsen hen til Troen, for Gud ydmygende sig under sin Svaghed" (SD, 117). Troen rodfæstes dog ikke i Sidenius, eftersom den fordufter i det sommerlige friluftsliv, han dyrker umiddelbart efter ligfølget (II, 127). Måske har Pontoppidans hensigt med denne skildring været, at han dermed atter bliver i stand til at gøre fortvivlelsens bevægelse på et højere bevidsthedsniveau med større berøring med sig selv.

\section{Lykke-Per-en trodsig fortvivlelse}

Trodsens fortvivlelse er en stigen i bevidstheden, da den " $\mathrm{i}$ en vis Forstand [ligger] det Sande meget nær; og just fordi den ligger det Sande meget nær, er den uendelig langt borte" (SD, 122). Som bekendt er trodsens fortvivlelse en fortvivlelse ved hjælp af det evige, hvor den fortvivlede ved at misbruge det evige i selvet ønsker at råde over sig selv på trods af den magt, som har sat det. Det kræver, at man har en bevidsthed om, at man er et selv, hvilket Sidenius er blevet bevidst om ved skibsoverfarten med sin døde moder til sin hjemegn. Den åndelige fødsel, Sidenius her oplevede, kan velsagtens forstås som en henvisning til Kierkegaards begreb om, at selvet er ånd, hvorfor Sidenius med andre ord nu ved, at han er et selv som en syntetisk enhed af endelighed og uendelighed, hvilket han i troen har ydmyget sig under. Det varer imidlertid som bekendt ikke ret længe, førend han opgiver den i en "værkbruden Præstekones Lignelse" nyfundne religiøsitet til fordel for det sommerlige friluftsliv på Kærsholm.

På Kærsholm stifter Sidenius bekendtskab med den glade grundtvigianer, pastor Blomberg: "en frejdig, trøstefuld Forkynder af et hyggeligt Hverdagsevangelium, som ikke krævede uoverkommelige Opofrelser i Henseende til Livets Behageligheder og derfor havde vundet mange Tilhængere" (II, 122). Det lyser ud af romanen, at Pontoppidan ikke selv agter denne slags prædikanter højt, hvad han i en kommentar tidligere har gjort klart:

Og se, da den fromme Klosterbroder havde faaet Spæk på Nyrerne, grebes han af kødelige Anfægtelser. Han fik Trang til at gifte sig, han følte det sluttelig som sin ligefremme Kristenpligt at blive Familjefader og uden Sværmeri dele Livets Goder med de andre Adamssønner. Kirken blandede Blod med det borgerlige Samfund (II, 118). 
Det er den samme borgerliggørelse, som pastor Blomberg repræsenterer, og som har vundet mange tilhængere for hverdagsevangeliet. Da Sidenius er blevet opmærksom på troens organ i ham, er det først og fremdeles denne kristendomstype, han giver sig i kast med. Således betages han af den blombergske kristendom, at han føler tilskyndelse til at anbefale denne pastors prædikener for den skeptiske Jakobe Salomon, da han er overbevist om, at disse vil "vinde hende for den kristne Livsanskuelse" (II, 176). Kristendommen, som Sidenius her har givet sig hen til, finder sit naturlige udtryk på Vartov i København, som han opsøger den første søndag efter sin hjemkomst (II, 220). Om Grundtvig hedder det i den forbindelse, at hans "Aand rugede endnu over Stedet, og fra hele Landet søgte man dertil som til en hellig Plet, hvor Gud paany havde aabenbaret sig for sit Folk i en brændende Tornebusks Lignelse" (II, 220). Den ironiske distance og bidende sarkasme synes at minde om skildringen af præstestanden ovenfor, idet Pontoppidan bemærker, hvordan solen skinner over menigheden og danner helgenskin om deres hoveder. Sidenius er på trods af sin velvilje ikke i stand til at høre efter, dels fordi han opdager, at hans søskende er til stede, dels fordi han måske ubevidst vægrer sig mod borgerliggørelsen af teologien, hvilket ellers tiltalte ham.

Det kan skyldes, at Blombergs kristendom var et trodsigt forsøg fra Sidenius på at omdanne sig selv. Hos Kierkegaard hedder det jo netop, at "et saadant experimenterende Selv, der fortvivlet vil være sig selv (...) [kan støde] paa en eller anden Vanskelighed" (SD, 124). Den vanskelighed, som Sidenius i denne sammenhæng er stødt på, er legemliggjort i anden præsteskikkelse, pastor Fjaltring. For de kristne, som samles hos pastor Blomberg, er Fjaltring til stor forargelse. De har bl.a. erfaret, at han sågar har opfordret en mand i menigheden til at synde noget mere, eftersom hans levned ingenlunde ville lade ham blive en overbevist kristen (II, 159). De livsglade kristne forstår sig ikke på denne "Uglenatur, et lyssky Væsen, ret egenlig en Mørkets Aand" (II, 149), som vækker deres afsky. Hos Sidenius har denne mystiske præst imidlertid en ejendommelig tiltrækning, hvilket bliver ham bevidst, da han ser Fjaltring på en af hans natlige vandringer: "Det var for ham, som havde han her set et Billede af sin egen Fremtidsskæbne" (II, 162). I forlængelse heraf mister den blombergske kristendom taget i Sidenius, da den "manglede overbevisende Kraft, hvor Talen var om Ofrene og Lidelsen” (II, 233), hvilket optager Sidenius mere, desto større erkendelse han kommer til. Han øger derfor også sine besøg hos pastor Fjaltring, hvor han møder en teologi, som står i et diametralt modsætningsforhold til den blombergske kristendom. Hos Fjaltring møder han bemærkninger som "Lykke i verdslig Forstand gjorde Mennesket goldt" (II, 277). Troen er en passion, 
hævder Fjaltring, der kræver kraft og anstrengelse, hvorfor den altså ikke lader sig tilvejebringe gennem verdslig tryghed og glæde, men snarere gennem sorgen og lidelsen (II, 277).

I den sammenhæng er det bemærkelsesværdigt, at han hævder, at selvudvikling alene lader sig gøre gennem tvivlen, der forårsages af sorgen og lidelsen. Fjaltring forstår troen som et produkt af tvivlen: "En Tro, som ikke bestandig fornyedes gennem Tvivl, var en livløs Ting” (II, 282). Her skal man ihukomme, at Sygdommen til Døden repræsenterer samme overvejelse, hvilket er anskueliggjort i nærværende artikel. Det er ligeledes i dette perspektiv, at opfordringen om at synde mere skal forstås, da synden medfører en tvivl og en trang til frelsen. Sidenius holder fast i Fjaltring, da han betragter ham som en "Lærer og Befrier" (II, 288), der gennem sit sorgs- og lidelsesevangelium hjælper ham til at anerkende "Den spøgelsesagtige Haand (...), der gennem hele hans Liv lønligt havde grebet ind i alle afgørende Øjeblikke for at lede hans Skridt” (II, 313). For at komme til sit egentlige selv, som Fjaltring har vist ham vejen mod, må Sidenius bryde med sit trodsige selv, hvilket bruddet med Inger symboliserer, idet hun som Blombergs datter i mangt og meget repræsenterer et trodsigt selv, han har forsøgt at skabe uden hensyntagen til den magt, som har forsøgt at lede hans skridt.

\section{Lykke-Pers selvtab}

Det kræver mod at tabe sig selv. Det må Sidenius også sande, da han bryder med Inger og deres fælles børn, hvor hans umiddelbare reaktion er at ville blive i den tilværelse, han i sin trodsighed har forsøgt at skabe: "Han vilde rejse sig og gaa derhen, - men Spøgelseshaanden holdt ham tilbage. Det maatte ikke ske! Afgørelsens store Time var kommen nu" (II, 325). I sin lydighed mod spøgelseshånden taber han i sin lidelse sit trodsige selv, hvormed han vinder hans egentlige selv. Den smertefulde bevægelse illustreres ved Sidenius' gøren: "Per rettede sig i Vejret, greb sig med Hænderne om Hovedet og stønnede. $\mathrm{Nu}$ var det gjort! Ofret var bragt! Og han lovede sig selv at holde ud til det sidste" (II, 330). Ligesom Abraham på Guds befaling måtte ofre Isak, således lader Pontoppidan Sidenius ofre sit trodsige selv i skikkelse af Inger og deres børn på befaling fra spøgelseshånden.

Sidenius' endelige bestemmelse tvinger ham altså til at bryde med Inger og deres børn, fordi "hun var jo ingen Trold" (II, 325). Væsensforskelligheden mellem Sidenius og Inger kan genfindes i Kierkegaards gendigtning af sagnet om Agnete og Havmanden, som den kommer til udtryk i Frygt og Baven. Her hedder det, at havmanden må lade Agnete tro sig bedraget, fordi han har indset deres forskellighed, hvilket ikke må skade hendes mulighed for at blive sig selv: 
"Han veed, at Agnete elsker ham. Kunde han fravriste Agnete denne Kjærlighed, da er hun paa en Maade frelst" (FB, 88). Således lader også Sidenius Inger sig tro bedraget, idet han går med på hendes beskyldning om utroskab, skønt han altså ikke har været det, men med det "Formaal at bringe hende til at hade og foragte ham: desto hurtigere vilde hun glemme ham" (II, 329). Georg Brandes anfører den betragtning, at forskellen mellem Abraham og havmanden består i, at Abraham "ikke ved Synd blev 'den Enkelte', men ved at være Guds Udvalgte". ${ }^{11}$ Abraham stod med andre ord i et absolut, ubetinget forhold til Gud, hvormed menes, at han som bekendt kunne suspendere det etiske med henvisning til Guds befaling. Sidenius står ligeledes i et absolut, ubetinget forhold til spøgelseshånden, hvorfor han suspenderer det etiske og bryder med sin hustru og børn i pligten mod det absolutte, som har sat hans selv og bestemmelse. I denne proces ser Sidenius sig ikke i stand til at meddele sig til Inger, hvorfor hun ikke begriber, hvorledes han kan resignere på deres forhold og på forholdet til børnene. Det umiddelbare forhold til en højere magt lader sig ikke oversætte i det etiske, hvilket er en lignende overvejelse i Frygt og Baven, idet Abraham jo netop heller ikke kan forklare, hvorfor han må ofre Isak, hans søn. Endnu mindre lader det sig imidlertid forstå, at Sidenius kan finde lykken i eller på trods af lidelsen. Her kan Kierkegaard atter være behjælpelig med begrebet om troen i kraft af det absurde; det absurde er netop, at man tror, at for Gud, eller spøgelseshånden i dette tilfælde, er alting muligt, når intet synes at være det. Således har også Sidenius opgivet alting:

En halv Time efter rullede Vognen ud af Gaarden. Per havde ikke rørt sig. Da den sidste Lyd af Hjulene tabte sig derude paa Vejen, løftede han det blege Ansigt op fra sine Hænder og vendte uvilkårligt Blikket mod Himlen.

"Er det nu nok?" (II, 331).

Direkte adspurgt om sin gudstro kort forinden har Sidenius afværget og sagt, at "for den, som er bleven sig sit eget Selv rigtig bevidst, er en Gud overflødig" (II, 327). Ikke desto mindre indfører Pontoppidan på denne helt centrale passus en henvendelse mod det guddommelige, hvormed man ikke bare kan afskrive muligheden for, at Sidenius faktisk har et forhold til noget guddommeligt.

For at vende tilbage til Børge Kristiansen, hvis tese om, at Kierkegaard og Pontoppidan er afgørende forskellige i forhold til gudsfor-

11. Georg Brandes, Søren Kierkegaard. En kritisk Fremstilling i Grundrids (København: Gyldendal 1967), 79. 
holdet i selvantagelsen, var anledningen til denne artikel, så hævder han, at "Gud er for Per i denne situation ikke nogen transcendent størrelse, der virkelig eksisterer for ham, men udelukkende en nødens vokabel, en fiktiv taleinstans" (Kristiansen 2007, 189). Det bliver dog svært at retfærdiggøre, at Sidenius må bryde med sin hustru og sine børn, såfremt denne guddommelige spøgelseshånd, som leder hans skridt, blot skulle være en fiktiv taleinstans. I så fald kunne man have forventet en større kynisme hos Sidenius ved bruddet, men Pontoppidan understreger netop hans afmægtige følelser ved bruddet, som ikke forekommer ham let. Han tvivler derimod til det sidste. Derfor må hans henvendelse mod det guddommelige altså også forstås i den retning, at hans bestemmelse og hans virkelige selv er nedlagt $\mathrm{i}$ ham af noget uden for ham, som han ikke er herre over eller kan kontrollere.

\section{Vejassistent Per Sidenius - kristen eller ej?}

Sidenius' sidste tid som vejassistent i en vestjysk flække lader til at være domineret af irreligiøsitet, hvilket får Kristiansen til at hævde, at anråbelsen ovenfor må være et nødens vokabel. Om Sidenius hedder det også, at han ikke havde "anden Uven end Præsten” (II, 331), ligesom han ej heller "søgte Trøst i Religionen, aldrig gik i Kirke, endsige til Herrens Bord, og derfor af Præsten blev betegnet som en af de Ulykkelige, der var hjemfalden til den evige Fortabelse" (II, 332). Afvisningen af kristendommens Gud bakkes op af de efterladte notater, man finder i Sidenius' dødsbo. Her hedder det bl.a., at man burde glemme Gud, i fald han fandtes, fordi hvad nytter de gode gerninger gjort i menneskelighed, når "der sidder en regnskabsførende Gud i Himlen og ser derpaa og nikker bifaldende?” (II, 341). Nærværende artikels sigte er dog i modsætning hertil at påpege nogle af de bemærkelsesværdige sammenfald med Kierkegaards overvejelser omkring religiøsitet, som Kristiansen ikke har haft øje for - og som er den naturlige kulmination på ovenstående analyse.

Man kan hævde, at Sidenius' irreligiøsitet skal ses i lyset af Pontoppidans egen kristendomskritik som en afvisning af et gudsbillede, hvor Gud sidder som en "regnskabsførende Gud i himlen", hvorfor man ikke opnår noget personligt forhold til ham. Det er ikke gerningen, det afhænger af, hvilket ellers præsten repræsenterer, da han på baggrund af Sidenius' manglende kirkegang har konstateret, at han må være hjemfalden til den evige fortabelse. Det hænger derimod sammen med det personlige forhold til Gud, passionen, liden- 
skaben. Uvenskabet med præsten er dermed ikke opstået som følge af præstens hverv, idet Sidenius' lærer og befrier selv var præst, men på baggrund af det gudsbillede, som præsten repræsenterer - og som ikke stemmer overens med hverken Pontoppidans eller Kierkegaards eget syn på troen. Derfor tilbringer Sidenius også langt størstedelen af tiden "med sig selv og sine Tanker" (II, 331), selvom han ellers har mange venner på egnen. Det ligger i forlængelse af den betragtning, at forholdet til Gud også hos Abraham er omgærdet af tavshed.

Da hans genbo derfor forsøger at begribe, hvorfor Sidenius trods sin ensomhed er lykkelig, forklarer han, at dette hænger sammen med evnen til at "lære den højeste Menneskelykke at kende: at blive sig sit eget Selv fuldt og klart bevidst" (II, 332). Denne bevidsthed vindes ved, at man finder sit naturlige voksested, hvilket han dog ikke kan gøre for genboen. Dette er genboens egen opgave:

\begin{abstract}
Men da Skolelæreren derefter spurgte ham, hvorledes man bar sig ad med at søge dette Voksested, svarede han, at herom kunde det ene Menneske ikke meddele det andet Raad, her maatte enhver frygtløst give sig det Selvudfoldelsens Instinkt i Vold, der var nedlagt i alt det skabte (II, 332).
\end{abstract}

Ligesom Abraham ikke er i stand til at oversætte sit forhold til Gud i det almene, således er Sidenius heller ikke i stand til at oversætte dette at blive sig selv for en anden; denne bevægelse må den enkelte gøre for sig selv ved at bringe sig i umiddelbar forbindelse med den magt, som har nedlagt selvets bestemmelse i selvet, hos Abraham Gud, hos Sidenius den ubestemte spøgelseshånd.

Denne spøgelseshånd kan man komme nærmere ved at betragte Pontoppidans brug af spøgelsesmetaforikken, som findes rundt omkring i romanen. Om selvudfoldelsens instinkt, som man skal give sig i vold, hedder det, at det er "en Stemme fra Dybet af vort Indre, en Spøgelsesstemme, der spørger: Men hvem er du selv?” (II, 338). At spøgelsesstemmen befinder sig i dybet af vort indre, tyder på, at Pontoppidan vil identificere spøgelsesstemmen med den enkeltes samvittighed, der som oftest er stemmen i det indre, der bedømmer vores handlinger ud fra et dybereliggende fundament. Samvittigheden er en medviden med sig selv, man ikke nødvendigvis kan udgrunde, men hvis befalinger man kan adlyde, såfremt man vil have "god samvittighed". Sidenius oplever det selv, da han forlader Inger og børnene, eftersom hans samvittighed byder ham imod at forblive i forholdet til Inger til trods for hans umiddelbare tilbøjelighed til dette. Det kræver imidlertid, man er bevidst om sin egen samvittighed, hvad Sidenius i allerhøjeste grad er blevet, efterhånden som han har 
ladet spøgelseshånden lede hans skridt. Det er en ganske overbevisende reference til Kierkegaards Kjerlighedens Gjerninger, hvori det hedder, at "Forholdet mellem den Enkelte og Gud, Guds-Forholdet er Samvittigheden". ${ }^{12}$ Det underbygger blot tesen om, at Sidenius tager afstand til den dominerende gudsopfattelse med en regnskabsførende Gud i himlen til fordel for en gudsopfattelse, hvor forholdet består i den enkeltes eget forhold til sig selv og sin "sathed" af det andet.

Dette "Andet" identificerer Kierkegaard som bekendt med den kristne Gud. Denne klippefaste forsikring kan man ikke overføre til Pontoppidan, som fastholder spøgelsesmetaforikken i mangel af et bedre ord. Dog kan man konstatere, at spøgelserne kommer til udtryk som kristne symboler. Således hedder det bl.a. om kirkeklokkerne, at de er "Spøgelsesglam" (I, 304) og om krucifikset, som Sidenius forsøger at henrette, beskriver han Kristus som et "Gespenst" (I, 303), altså et andet ord for spøgelse. Dertil er han i sin sidste tid væsentligt optaget af spørgsmål om troen, hvor det om Kristus i hans efterladte papirer hedder, at han "lærer os i Virkeligheden intet ud over dette (som er en gammel Visdom), at der kun er eet, der overvinder Lidelsen, og det er Passionen" (II, 340). Sidenius afviser ikke kristendommen her, men stadfæster den derimod som udtryk for en gammel visdom, der blot har fundet sit naturlige udtryk i Kristus-dyrkelsen. Abraham var i tiden før inkarnationen, men også han overvandt lidelsen og smerten ved at ofre sin søn, fordi han ved at stå i et absolut, ubetinget forhold til Gud troede i kraft af det absurde. Troen var for ham passion og lidenskab, ligesom "troen" i skildringen af Sidenius er passion og lidenskab, fordi han igennem denne har fundet sit selv, som er blevet nedlagt i ham af noget andet.

Betyder det så, at Sidenius ender sine dage som en art kristen munk? Pontoppidans spøgelse ville givetvis hjemsøge overtegnedes studerekammer, såfremt det blev konklusionen på nærværende artikel. Det må tages for pålydende, at Sidenius ikke søger kirkens rum, at han afviser sin næste til fordel for sig selv etc., hvorfor man ikke kan betragte ham som en traditionel kristen skikkelse. Det ændrer ikke på, som artiklen forhåbentligt har anskueliggjort, at Pontoppidan i sin portrættering af Sidenius' selvantagelse har været væsentligt inspireret af Kierkegaards antropologi. Pontoppidan lader Sidenius formulere, at det handler om at have "et eventyrligt Mod til at ville sig selv i guddommelig Nøgenhed" (II, 340). I overensstemmelse med den her præsenterede læsning kan en udlægning være, at man i sit ubetingede og absolutte forhold til det "Andet", den guddommelige

12. Søren Kierkegaard, Kjerlighedens Gjerninger, Søren Kierkegaards Samlede Værker 12 (København: Gyldendal 1962), 140. 
nøgenhed, må have et mod til at tabe sit trodsige selv for at ville det selv, som er nedlagt i det skabte. I Sygdommen til Døden er det således kun den kristne, der har modet til at tabe sig selv og dermed vinde sig selv, fordi han som kristen er blevet bevidst om sygdommen til døden, nemlig fortvivlelsen. Dette mod får Sidenius, fordi han konfronteres med Fjaltrings og dennes hustru tragiske endeligt. Deres ægteskab fastholdt dem i fortvivlelsen, fordi Fjaltrings hustru ingenlunde kunne tilpasses til Fjaltrings gemyt, der på sin side vidste, at han ikke kunne leve op til den ægteskabelige fordring. Fortvivlelsen blev for Fjaltring en virkelig sygdom til døden, hvorfor Sidenius kan bryde med Inger, da han ved, at såfremt de ville blive fastholdt i fortvivlelsen, da ville de begge miste livet. På befaling fra den ubestemte spøgelseshånd afværgede han således fortvivlelsen, hvilket også Inger indser langt senere, hvor hun i en skrivelse takker Sidenius for hans brud med hende (II, 339).

Konklusionen må derfor være, at man ville forvente en utvetydig tilslutning til kristendommen, i fald man skulle konstatere, at Sidenius ender som kristen. Pontoppidan ønskede ikke en sådan læsning, men ovenstående analyse vidner om, at romanen indeholder langt mere religiøsitet og flere religiøse anskuelser, end forfatteren måske selv har været bevidst om eller i alt fald intenderet. Lykke-Per rummer under alle omstændigheder væsentlige ligheder med Kierkegaards antropologi, som ikke nødvendigvis kan forklares gennem et filologisk gravearbejde, men på hermeneutisk vis kan udlægges. Det betyder i sagens natur også, at læsningen her ikke gør krav på hele sandheden, men måske snarere kaster lys over et interessant område i læsningen af Pontoppidans forfatterskab. 